\title{
An Appraisal of Malaysia's Continuing Membership in the Commonwealth Organisation
}

\author{
Muhammad Muda \\ Nazariah Osman \\ School of International Studies \\ UUM College of Law, Government and International Studies
}

\begin{abstract}
The Commonwealth has always had a central place in Malaya/Malaysia's foreign policy, especially in the period immediately after independence and in the first few years of the formation of Malaysia. This was the period when Malaysia needed Commonwealth assistance most, in part, due to its requirement for external defence. Such assistance was not only relevant in the context of constructive cooperation but, more importantly, there was no other organization at that time in the region that could be of assistance to it. Whilst Britain was keen at accommodating Malaya as a member of the organisation upon independence, it were the Prime Ministers of Malaysia who played decisive roles in determining the extent of the relationship with the Commonwealth. The benefits Malaysia derived from such association were also heavily shaped by the styles and perceptions of successive Prime Ministers. Although the emergence of ASEAN, OIC, and other similar bodies in later years of which Malaysia is also a member, has gradually eroded Malaysia's profound attachment to the Commonwealth, however, it has no intention of leaving the Commonwealth. It has continued to offer some degree of both tangible and intangible support to the organisation in which successive Malaysian Premiers have acknowledged its relevance to the country's foreign policy as well as it being a useful platform to articulate Malaysia's views on political and socio-economic matters concerning, not only Commonwealth countries, but also the world at large.
\end{abstract}

Keywords: Malaysia, Commonwealth, Relevance, Continuing Relations.

\section{Introduction}

The Commonwealth was the first international organization which the then Malaya joined as its tenth member in 1957 and remains so to this day. What should also be borne in mind is that Malaysia's membership was coterminous with the country's independence, though it is seldom mentioned. Today the Commonwealth has 53 member countries, all of which were former British colonies spreading across five continents. Malaysia's membership in the Commonwealth raises several questions that may require some evaluation and assessment as to recent past and current policy on the Commonwealth. These assessments also involve judgments about its contribution to the organization and the likely responses to its conduct 
on issues or problems. The pertinent questions are: first, the reasons that prompted the then Malaya to join the Commonwealth; secondly, the extent to which the Commonwealth was, or still is, relevant to Malaysia's foreign policy; thirdly, the extent to which Malaysia has derived benefits from its membership; and finally, the degree of its involvement in this organization, including its participation in the programmes organized by the Commonwealth Secretariat.

\section{Genesis of the Commonwealth}

Any discussion on the Commonwealth would not be complete without first briefly looking at the origin of Commonwealth itself. The Commonwealth is the term now officially used to designate this voluntary organization of 53 independent sovereign states that evolved out of the once mighty British Empire. The then British Empire was not only the largest political community in the world it was also the most varied in terms of geographical, racial, cultural and religious diversity. Within the borders of the British Empire lived one-quarter of the inhabitants of the globe - Europeans, Asiatics, Africans, Australiasians and Americans - of whom the vast majority were governed from London. These communities were at different stages of political development. Therefore the responsibility of governing the Empire was far greater than any political responsibility that fell on any British statesmen of that time. And, given the great difficulty in managing such vast overseas possessions, the Empire gradually came to a close after the first half of 1900, resulting in many more colonies gaining self-rule status. This was also a period in which the name British Empire changed to British Commonwealth of Nations, which was popularized by General Jan Christiaan Smuts, the then Prime Minister of South Africa. ${ }^{1}$ In 1949 the adjective "British" was dropped to reflect the changing nature of the association and since then it became known as Commonwealth of Nations, or now, just the Commonwealth. So the Commonwealth was not consciously or formally set up at any one moment, but evolved out of the British Empire, in which the sun never set. Indeed the modern Commonwealth started in 1947 whilst the existence of the 'old' Commonwealth could be traced back to hundreds of years before this. Commonwealth, has almost as many interpretations as to its basic character as there are writers on the subject. Perhaps one of the best descriptions is what K.C. Wheare wrote in early 1952: "If the Commonwealth did not already exist, it would be impossible to invent"2 or, we might add, even to conceive one.

Many former colonies became members of the Commonwealth after the $2^{\text {nd }}$ World War, namely, India in 1947 followed by Pakistan and Ceylon (now Sri Lanka). Several countries in Africa also joined the Commonwealth on attaining independence in the 1960s. According to A. J. Cross, a British academic, "if the Commonwealth ever had a golden age it was surely in the 1950s". ${ }^{3}$ The "golden age" referred to by Cross draws attention to the transformation of the Commonwealth from the white man's preserve to a unique multilateral association of equals, following the independence of many ex-British colonies and then their decision to retain links with the Commonwealth. However, this did not mean that it was mandatory for former British colonies to become members of the Commonwealth. Some colonies 
preferred not join or later decided to withdraw from the organization. Burma did not join the Commonwealth after becoming independent in 1948 and Ireland too, chose to be outside the Commonwealth when it obtained independence from Britain in 1949.

Commonwealth has also admitted new members which were not part of the British Colonial Empire such as Mozambique and Rwanda. However, it has been recognized that the transformation of a once mighty colonial empire into the present day association of fiftythree member nations may be regarded as a remarkable achievement. This transformation prompted Arnold Smith, the first Secretary General of the Commonwealth (1965-1975) to say "a hundred years from now ... historians will consider the Commonwealth the greatest of all Britain's contribution to man's social and political history". ${ }^{4}$

\section{Commonwealth as an International Organisation}

We shall now consider in what sense the Commonwealth represents an international organisation' and why many former British colonies were attracted into joining it immediately upon attaining independence from Britain. An understanding of this concept is important as the Commonwealth is often nowadays regarded one of the longest surviving international organization, acquiring international respect and status as well as performing international roles. In his essay, William Dale, Legal Advisor to the British Foreign and Commonwealth Office, makes reference to academic authorities, Fawcett and Crawford, who had described the Commonwealth as "a kind of international organization" and "a kind of residual international organization" respectively. ${ }^{5}$ An Australian scholar, Bruce Miller, offered another view where he questioned: "How are we to classify it (the Commonwealth) as an international entity? It has no written constitution like the United Nations and its specialized agencies; it can hardly be called an international organization ... Its members are not even united by a common treaty of understanding. It is not a Zollverein. It is not a community. In fact it does not fit into any of the recognized international categories. Yet I have insisted that it is a going concern. Which name would suit it best? My own choice is to call it a concert of convenience". 6 This was an appropriate description of the Commonwealth in mid-1950s and early 1960s, that is, prior to the establishment of the Commonwealth Secretariat in 1965.

Dale's exposition was implicitly supported earlier by J.D.B. Miller who wrote: "The Commonwealth does not have a constitution, but it does have institutions which are outward signs of its existence... The institutions of the Commonwealth as they stood in 1964 are divided into four kinds: the Crown, the rights of members to enter or leave the Commonwealth; means of consultations between members; and institutions shared between members in order either to enrich the Commonwealth association or to further the joint and several interests of the members". ${ }^{7}$ Margaret Ball ${ }^{8}$ and Margaret Doxey ${ }^{9}$ have each expressed similar opinions on what constitutes an association and an international organization. They claimed that the Commonwealth does not need a constitution, and what is essential is for 
the Commonwealth to be active internationally, since the more effectively it acts the more it acquires the status commonly referred to as international personality.

Without doubt, the Commonwealth has all the essential ingredients, including a functioning Secretariat, necessary to qualify for the status of an organization capable of international action. Indeed, the Commonwealth Secretariat provides the machinery to run the organization, without which any organization cannot hope properly to organize and implement its objectives in the long-run. In view of its large increase in membership since 1957, such a set-up is needed to coordinate and facilitate intra-Commonwealth activities. Until 1965 the Commonwealth has had no such machinery, and all Commonwealth activities were organized and coordinated by the British Civil Service in the Whitehall in London. Clearly with changing times it is unthinkable for an association as large as the Commonwealth to function at all efficiently without a properly constituted bureau or secretariat.

It is interesting to note that the Malaya's membership in the Commonwealth was partly inspired by India's accession to Commonwealth membership. Recalling on the influence of India, or rather Jawaharlal Nehru, in transforming the Commonwealth into a new association of equals that serves all members, Malaya gave particular attention to that part of Nehru's speech over radio in New Delhi on 10 May 1949 in which he said: "It may be remembered that the Commonwealth is not a super-state in any sense of the term. We have agreed to consider the King as the symbolic head of this association. But the King has no function attached to that status in the Commonwealth. As far as the constitution of India is concerned, the King has no place and we shall owe no allegiance to him". ${ }^{10}$ Nehru's speech, according to Ghazali Shafie, then a senior bureaucratic and later Permanent Secretary to Malaya's Foreign Ministry, had a tremendous influence at the time when Malaya was preparing for independence. He further added that had India been unsuccessful in bringing about these changes in Commonwealth relations, it is doubtful if Malaya's decision to retain monarchial institution and at the same time remain in the Commonwealth would have been favourably considered. ${ }^{11}$

\section{Factors that Prompted Malaya Joining the Commonwealth}

\section{British Colonial Rule}

If there is one factor which may be cited as the principal reason for Malaya's membership in the Commonwealth after independence it is the British legacy - the outcome of eighty-three years of British rule in Malaya. Over the years some substantial ties developed - political, economic, educational, legal, military and cultural with Britain. British rule also produced by 1940 s and 1950s Malayan elites who were convinced that closer links with Britain and full membership of the Commonwealth would be a crucial facility for the realization of Malayan, later Malaysian, national interests. Further, it was certainly the preferred British policy that its colonial territories, including Malaya, as they reached self-government, 
should remain in the Commonwealth. ${ }^{12}$ The final decision to grant independence to Malaya was reached in February 1956 when the Constitutional Conference, which met in London, agreed that full self-government and "independence within the Commonwealth" for Malaya should be proclaimed on 31 August 1957.

\section{The Security Circumstances in Malaysia}

A second reason for then Malaya joining the Commonwealth was its earnest desire to maintain close relations with such friendly countries as Britain, Australia, New Zealand and Canada, who had generously offered their support and assistance during the Emergency, purportedly supported by Communist China; the "Konfrontasi" arising from Indonesia's claim that the formation of Malaysia was a 'neo-colonialist plot' and that it was a conscious attempt by Britain to perpetuate its influence in the region; and the Sabah dispute in which the Philippines exerted their sovereignty, jurisdiction and proprietary ownership, as successor to the heirs of the Sultan of Sulu, over the whole of Sabah. ${ }^{13}$ The support given to Malaysia by the 'old' members of the Commonwealth was seen as an outstanding example of constructive cooperation between the old and the new Commonwealth members.

Another major security reason for Malaya's accession to Commonwealth membership was the political circumstances in the region at the time as evidenced by the 'Cold War' which had divided the region into East-West confrontation along ideological lines between communist countries and western-led democracies. For Malaya, accession to Commonwealth membership, though seen as adopting a pro-west policy, was considered the correct path in the context of securing military assistance and other logistical support against outside interference over the sovereignty of a 'small' and newly independent country.

\section{Malaysia - Commonwealth Relations Since Independence}

For a better understanding of the continuity of the Malaysia-Commonwealth relations, it is also vital to have a picture of the country's links with the organization during successive prime ministers namely Tunku Abdul Rahman, Tun Abdul Razak, Tun Hussein Onn and Dr Mahathir Mohamed. In Malaysia there is much evidence to suggest that prime ministers have invariably taken a major personal interest in foreign relations with countries and in intergovernmental organisations. The cabinet system of government, (Parliamentary System) to a very considerable extent, allows successive prime ministers wide power in foreign affairs. Moreover, the absence of a Cabinet Committee on Foreign Affairs, along the lines of the UK Parliament Select Committee on Foreign Affairs, as well as the lack of debate in Malaysian Parliament on foreign affairs help explain the important role its prime ministers play in formulating and articulating foreign policy. The Malaysian Parliament itself plays no role in foreign policy development, and references to foreign relations usually revolve around a ministerial answer to parliamentary questions, usually about expenses and visits by the Prime Minister or Foreign Minister to other countries, or to seek clarification 
on Malaysia's preferred position on events taking place elsewhere. Perhaps it may be of interest to mention that foreign policy issues have never interrupted or caused a break of government in Malaysia. The fact that Malaysia has enjoyed an uninterrupted membership in the Commonwealth since 1957 is indicative of the support, styles and concerns which each prime minister brought to the organisation.

\section{The Role of Tunku Abdul Rahman}

It cannot be denied that the prime-mover for Malaya becoming a member of the Commonwealth was Tunku Abdul Rahman, the first Prime Minister of independent Malaya. The Tunku was always ready to say that it was a useful association and in defending it he was quoted as saying "We have made our choice. That choice is with the Commonwealth, and it is irrevocable. We will either float or sink with our British friends and the great Commonwealth which their leadership has inspired". ${ }^{14}$ Expressing much the same sentiment several years later he added: "Malaya has been a staunch supporter in all fields of activities connected with the Commonwealth and will do all she can to make the Commonwealth a living force". ${ }^{15}$ In fact, the Tunku was emphatic that membership did not in any manner obstruct Malaysia in carrying out its own independent policies and objectives in international affairs.

There may be several reasons to account for the Tunku's strong affinity for the Commonwealth. First, was his strong sentimental attachment to Britain and one way of retaining this link was through the Commonwealth. The attachment he had with Britain, in part, stemmed from his early exposure to the British education system but it was also based on his recognition of the pragmatic need for Britain to assist Malaya in the face of the many problems which independence entailed. Many of his political colleagues in the United Malay National Organisation (UMNO)/Alliance and senior bureaucrats, many of whom were also the product of western education, shared the Tunku's sentiments. But of course these emotional sentiments and pragmatic calculations of Tunku unfortunately, had not permeated the rank and file of Malayans generally.

A second reason was the Tunku's strong view on the multi-racial character of the Commonwealth. Its membership comprises races and religions spreading across five continents. The plural nature of Malayan society which the Tunku helped to nurture was aptly put by Nicholas Mansergh: "makes acceptance of the Commonwealth, itself a plural society, easier and also more practical, since the Commonwealth provides one means for the exchange of information on the easing of ethnic tension". ${ }^{16}$

Another very important reason that prompted Tunku to join the Commonwealth was because, as mentioned earlier, due to the security situation in Malaysia and in the region prevailing then. The Tunku worked indefatigably in winning support from 'old' members of the Commonwealth in fighting the communists, defending against Indonesia's confrontation, 
endorsing the formation of Malaysia and obtaining military support through the Anglo Malayan Defence Agreement (AMDA) and later the Five Power Defence Arrangement (FPDA). Though the later body is not directly under the auspices of the Commonwealth, none the less it operates in the spirit of bilateral cooperation between Commonwealth members.

\section{Tun Abdul Razak Hussain}

Tun Abdul Razak succeeded Tunku on 22 September 1970 against a background of a serious race riots that occurred on 13 May 1969 in Malaysia. His premiership also witnessed some important external events taking place in the East and Southeast Asia, namely the proposed US military disengagement in Asia, the British pull-out East of Suez, the rise of Communist China and it assuming China's UN seat, and China-US rapprochement. All these events prompted Razak to embark on a review of Malaysia's foreign policy priorities including Malaysia's relations with the Commonwealth in the changing political relations in the region.

Speaking in Parliament on his new foreign policy priorities he said: "In formulating and executing our foreign policy we cannot take a theoretical view of things. We can only proceed by accepting the world as it is, and by so managing our affairs as to ensure the integrity and sovereignty of our country" ... and added "We are living in a world very different from that which we obtained up to a few years ago ... we will adopt a foreign policy that is careful, coherent, far-sighted in conformity with our principles and our basic national interest to ensure our own security and our own stability". ${ }^{17}$ Security here did not mean just external security or military security. Political security was seen as a fundamental aspect of the national security of Malaysia.

Razak, together with the Tunku, was privy to all foreign policy matters affecting Malaysia, including his support for Commonwealth membership in 1957. For Razak, the Commonwealth was a practical instrument not only for the political and economic policies but also for strengthening relations with other countries. Like Tunku, he recognized that it did not restrict Malaysia's independent foreign policy and he showed and expressed his support by attending most Commonwealth Heads of Government Meetings (CHOGMs), first as Tunku's deputy and then as prime Minister.

Although Razak thus continued to support the Commonwealth, it could be said that he was not as enthusiastic as the Tunku was. Unlike the Tunku, Razak had less sentimental regard for the links with the organization in particular, and Britain in general, though he felt very grateful to those members, such as Britain, Australia and New Zealand, which had contributed significantly to the defence of the then Malaya, and later Malaysia. Razak's attitude can be viewed from two perspectives: first, he had spent a much shorter time in Britain than the Tunku, and was not much influenced by the British ethos; secondly, when he assumed office the pattern of power relations in the region was different from the time of 
independence. He saw relations between most of the member states revolved less and less around the commonwealth connection. Despite this, Razak felt it was sufficient to 'keep' Malaysia's membership alive but not to 'overplay' it, as other regional and international organizations to which Malaysia belonged also required support. Hence there was a gradual erosion of the British influence as well as the significance of the Commonwealth in Malaysia's foreign policy.

For Razak, the Commonwealth "in its present form is neither dead nor dying." He added that although there is no constitutional or legal tie that binds together countries of the Commonwealth ... its members are agreed on one vital principle, that they seek to preserve this Commonwealth of free peoples as an instrument through which they, together with other nations, which share their objectives, can cooperate for the common good and for the preservation of world peace". ${ }^{18}$ On Malaysia's adhesion to Commonwealth membership, Razak argued that there was nothing to be gained by staying away from the organization which already existed and had brought benefit to its members, even if these benefits were relatively small.

\section{Tun Hussein Onn}

Hussein succeeded Razak as Prime Minister of Malaysia following the latter's untimely death in January 1976. Hussein made no major changes in the basic foreign policy which Razak had laid down. Hussein, for his part, did not advance any new foreign policy initiatives in the international politics of Southeast Asia. But Hussein continued to consolidate those foreign policies laid down by his predecessor.

With regard to the Commonwealth, there is no evidence to suggest that Hussein was critical of the organisation. After all this was an organization which his predecessors had approved of and had decided to join at the time of independence based on the fact that it was in Malaysia's interest to become a member and continue to remain in the Commonwealth. Hussein reiterated his support for the Commonwealth in his opening statement at the Commonwealth Heads of Government Meeting (CHOGM) held in London on 10 June 1977, which was the first CHOGM he attended. He said: "I also bring with me the tradition of strong support for this unique institution, the Commonwealth of Nations, and the high ideals that it stands for. Even before independence, my late father, had sought to identify my country with high aspirations of the Commonwealth" ... "I would like to give you my assurance of our continuing support and express the hope that the Commonwealth will grow to be more meaningful and effective in the years ahead". ${ }^{19}$ Hussein stayed away from the Lusaka CHOGM (1-7 August 1979) due to his poor health but sent his then Foreign Minister, Tengku Ahmad Rithauddeen, to represent him.

It needs to be mentioned that Hussein's strong support for the Commonwealth can be explained in terms of similar factors that had influenced his predecessors (Tunku and Razak). First, Hussein had a long association with Britain and its administration dating back to before Malaya's independence. Secondly, was his exposure to British tertiary education 
and to the political and social systems during his stay in England. Beyond this, Hussein found no reason to critcise Malaysia's close connection with the Commonwealth which his predecessors had made to work, and which had served Malaysia's foreign policy interest well in the past.

\section{Tun Dr. Mahathir Mohamad}

Mahathir became the fourth Prime Minister on 16 July 1981, succeeding Hussein Onn who stepped down because of poor health. Mahathir's tenure of office deserves special consideration because early in his premiership he put Malaysia's connection with the Commonwealth to a severe test and then subsequently went on none the less to host Kuala Lumpur CHOGM in September 1989. Mahathir assumed office against a background of greatly improved political stability in the country as well as in the external events affecting Malaysia. This was in marked contrast with the internal and external difficulties which had previously prevented the Tunku and Razak from doing more in foreign policy, including undertaking high profile engagement overseas.

Mahathir came to office as a forthright, tough and hard-hitting man with an intense sense of responsibility. With regard to foreign policy, Mahathir's approach did not involve drastic changes in substance, rather he brought robustness and assertiveness to policies which were previously lacking. One departure from the previous policy was a shift from traditional association with the west, while still maintaining close diplomatic and economic relations with them was necessary. His 'reorientation', however, was seen as a followup to the policies that Razak had initiated. But Mahathir went a step further in ensuring that Malaysia was not trampled on by others and hoped the country would emerge as a developed country which could enjoy much the same international respect as any other developed nation enjoyed without having to lose its own cultural and spiritual values. Again, in contrast to his predecessors, Mahathir had no hesitation in offering brusque opinions about matters affecting Malaysia's interest. Those familiar with his style and approach are often tempted to praise Mahathir for giving his country much more diverse and vibrant, and at times controversial, policies. This approach, however, reflected Mahathir's experience and perception of world events, and his own conception of Malaysia's proper role on the international stage.

In this regard, one foreign policy matter which evoked conflicting emotions during Dr Mahathir's administration in the early 1980s was the Commonwealth. Since becoming a member in 1957 no controversy over Malaya and then Malaysia's membership was recorded during the first twenty-three years. Neither was there evidence to suggest that Mahathir had an inbuilt suspicion of international organisations, though he had quite often expressed reservations about the roles and performances of some of them such as the Organization of Islamic Conference, Non-Aligned Movement, ASEAN or even the United Nations. But, the Commonwealth was the first international organization to receive public reprimand from Malaysia's Prime Minister. Mahathir felt that the Commonwealth had engaged in "too much 
talk with no tangible results". ${ }^{20}$ This explains why the Commonwealth was relegated to last place in Mahathir's first publicly declared order of Malaysia's foreign policy priorities. The question that is often asked is: What went wrong? There were several reasons to account for this.

First, Mahathir linked the Commonwealth too closely with Britain. He seemed to blame the Commonwealth for many unwelcome features of Britain's policies toward Malaysia or whenever Britain was at odds with the majority view already agreed by Commonwealth members. Such an approach was in direct contrast with the basic perception of the Commonwealth held by his predecessors. The Tunku, in particular, insisted that it was not proper for Malaysia to take on the Commonwealth on grounds of disagreement with Britain on specific bilateral issues, such as higher university tuition fees, extra landing rights for Malaysia airlines, criticism over Malaysia's acquisition of British plantation company, Guthrie, on the London Stock Exchange, the Pergau Dam project, and the reclamation of Carcosa Hill. ${ }^{21}$ In response to these bilateral difficulties with Britain, Mahathir even instituted a Buy British Last Policy which unfortunately did not last, while at the same time he introduced the Look East Policy instead.

Secondly, Mahathir already had reservations about the Commonwealth long before he became Prime Minister. He described his predecessor's foreign policy, particularly that of the Tunku, as influenced by an apron-string complex manifested in the defence treaty with Britain in the Anglo-Malayan Defence Agreement (AMDA), the presence of Australian and New Zealand forces without the formality of an agreement, the membership and firm belief in the Commonwealth" and further argued that the "confidence in Malaya and Malaysia as a truly independent country was lacking". 22 These perspectives have evoked varying responses. Given the political realities of Southeast Asia at that time and the political events affecting Malaya, one wonders why the policy nurtured by the Tunku was considered out of place. Independence should not mean refusal to cooperate with Britain or other Commonwealth partners. A defence agreement with them was, therefore, one form of cooperation between sovereign states.

AMDA was formally abrogated in 1971 and was replaced by the Five Power Defence Arrangement (FPDA), involving the five original "partners" of AMDA. FPDA does not resemble AMDA but takes a new form of defence cooperation. Unlike AMDA, the FPDA does not automatically commit Australia, Britain and New Zealand to come to the defense of Malaysia in the event the country is under attack. The arrangement merely provides consultation and, at regular intervals, conducts joint military exercise for the purpose of deciding what measures should be taken jointly or separately in relation to such attack or threat. Whilst Malaysians generally held the view that the FPDA still retains or provides that Commonwealth link, Mahathir condemned this arrangement as "worth less than a scrap of paper". ${ }^{23}$ What has puzzled many observers is that despite his critical view of FPDA before he came to power and, given his twenty-two years as prime minister, he did nothing to wreck FPDA but offered it as 'psychological' support and a sense of belonging to a group of like-minded countries that share similar aspirations and security concerns. ${ }^{24}$ 
Thirdly, Dr Mahathir's own preference was bilateralism rather than multilateralism. In defending his preference he said on 15 July 1982 in an interview coinciding with his first anniversary in office: "We find that bilateral relations enable us to know people more intimately, know what their problems are and how we can work with them, whereas the multilateral approach of the past has not been yielding that kind of intimacy and understanding ... I think by and large, the foreign policy we [Mahathir] have mapped out is good for us because it is a much more positive policy". ${ }^{25}$

Viewed in this light, would not such a preference contradict or at least qualify Malaysia's participation in ASEAN, OIC or other multilateral institutions? Perhaps Mahathir had dismissed the significance of multilateralism too soon. Speaking on foreign policy several years later, the then Malaysia's Foreign Minister, Abu Hassan Omar, commented: "Multilateralism will continue to be another priority for our foreign policy ... We see multilateralism playing a crucial role in helping to promote solutions of the many problems that confront us ... It is for this reason that Malaysia has been an active participant in such international organizations like the UN, the Commonwealth, ASEAN, the NAM, the Group of 77 , and the OIC". ${ }^{26}$

However, despite his early misgivings, or rather disenchantment with the Commonwealth, Mahathir showed no intention of wrecking it, though many have speculated that his instructions to the Malaysia's Institute for Strategic and International Studies (ISIS), a quasigovernment think-tank, and the Ministry of Foreign Affairs to undertake a review of Malaysia's membership in the Commonwealth, was aimed at taking the country out of the organization. In fact, the reviews ${ }^{27}$ which incorporated many recommendations were used by Mahathir to fathom out what the Commonwealth could possibly and practically mean for Malaysia. Some practical examples of his continuing support were his decision to offer Kuala Lumpur as host to two major Commonwealth events: the biennial Commonwealth Heads of Government Meeting (CHOGM) in September 1989 and the Commonwealth Games in 1998, both of which helped enhance the profile of Malaysia's foreign policy in the Commonwealth as well as proof of Malaysia's remaining in the organization, though in a much lesser role.

At the Kuala Lumpur CHOGM Mahathir was elected to Chair the High Level Appraisal Group (comprising 10 Heads of Government which had hosted CHOGMs since 1971), whose task was to identify possible roles which the Commonwealth might need to play beyond the 1990s and recommend as solutions to the inadequacies of the present Commonwealth. Given his 'renewed' interest, Mahathir had no qualm about accepting it as this also afforded him the opportunity to make some notable contribution to the review of the Commonwealth, an organization which he often criticized for not doing enough, or to quote two of his earlier critical phrases "a talking shop" and "too much talk and nothing tangible". His other major achievement was to bring the Commonwealth Games to Malaysia, a country not known for hosting international sporting events. ${ }^{28}$ 
Besides the two major Commonwealth events described above, Mahathir also welcomed Malaysia's other roles, even though minor, to reflect his new-found support for the organization, and these, among others, are mentioned below:

i. Membership of the eight-member Commonwealth Ministerial Action Group on Harare Principles (CMAG) on fundamental values such as democracy, human rights, rule of law, independence of judiciary. Malaysia has served four times in the twoyear term in CMAG - 1995-97, 1999-2001, 2005-07 and 2007-2009 - whose remit was to deal with member countries that breached or found persistently in violation of the principles contained in the Harare Declaration, especially the overthrow of democratically elected government by unconstitutional means.

ii. Hosted the headquarters of Commonwealth Tourism Centre in Kuala Lumpur.

iii. One of the seven Commonwealth countries (also including Australia, Canada, India, New Zealand, Singapore and UK) to make annual financial contributions to the budgets of the Joint Office for Commonwealth permanent Missions to the United Nations. The Joint Office provides accommodation and facilities for the ten least developed member countries to enable them to maintain representation at the UN. These countries are: Belize, Dominica, Gambia, Grenada, the Maldives, Nauru, Samoa, the Seychelles, Soloman Islands, and Tuvalu. The Joint Office is an independent legal entity administered by the Commonwealth Secretariat.

It should be mentioned here that little could be said about the role played by Tun Abdullah Ahmad Badawi, Mahathir's successor, as his tenure in office merely consolidated the policies of his predecessors towards the Commonwealth. And, any discussion on the role played by the current Prime Minister, Najib Abdul Razak, is bound to be interim and provisional. Indeed, it will remain so for several years, or even longer, until he leaves office.

The above paragraphs highlighted the variety of approaches taken by the first four prime ministers with regard to membership of the Commonwealth. Despite the different perspectives each prime minister brought to this organization, all of them have acknowledged that Malaysia should retain its membership in the Commonwealth which they regarded as being compatible with maintaining good relations with other countries and numerous international instruments of which Malaysia is also an active member. Interestingly, there is no record suggesting of any attempt to withdraw or suspend from membership of the Commonwealth - thus Malaysia being on record for enjoying uninterrupted association with this international organization since 1957.

\section{Malaysia's Role in the Commonwealth}

This section seeks to examine the responsibility and role of Malaysia toward the organization. Generally, it has a two-fold responsibility, namely to uphold the values of the organization 
so as to provide a unifying element and to ensure the fullest possible degree of continued cooperation with other members in pursuit of national objectives. At the same time a member must provide the means to realize the objectives or programmes laid down by the organization, or at least those that they perceived as useful. For the organization to function well it is not sufficient to expect what the organization can offer to members but, equally important, the level of member's participation has a direct bearing on the effectiveness of an organization.

Virtually all international organisations are dependent on financial support from members in order to continue in existence and carry on their work. Those financial contributions, together with other contributions of a material nature, constitute the most visible costs of membership..$^{29}$ Britain, for instance, is the largest single contributor to the budgets of the Commonwealth Secretariat and it also provides, among others, a building for the Secretariat at Marlborough House in London, while the other member countries also share the brunt of financial contribution as an important measure of member support for the organisation. Financial contributions to the Secretariat budget are on an agreed scale based on population, national income and capacity to pay, and the UN scales are used as a broad guide. Malaysia, in particular, has contributed its fair share to the budget of the Commonwealth Secretariat. Malaysia now stands as the eighth largest contributor, after Britain, Australia, New Zealand, Canada, India, Singapore and Brunei, to the budgets of the Commonwealth, which is indicative of its continuing and strong support. It also contributes to the Commonwealth Science Council, Commonwealth Youth Programme, Commonwealth Fund for Technical Cooperation and the Commonwealth Foundation. In addition, Malaysia has participated in many Observer Missions organized by the Commonwealth Secretariat to monitor general elections in member countries that requested for such a mission and, in supporting this exercise Malaysia provided financial assistance to the Secretariat so that Malaysian officials could also be included in the team.

The other form of support is expressed by the contribution of personnel to work in the organisation's Secretariat. Given Malaysia's financial support, it is expected to nominate its qualified nationals, normally from the country's civil service, for appropriate positions in the organization, but this was, and still is, lacking when compared to nationals nominated by other member states. There are two reasons for this: first, it is not the preferred strategy of government to provide special exposure to our public servants in the working of international organisations; and secondly, there is a view to suggest that Malaysia's public servants are already comfortable in their country with facilities adequately provided for by their government and, therefore, working in the international secretariats are not a motivational factor. In 2009, the Commonwealth Secretariat employed 305 international staff, of whom 4 were Malaysians, and all were candidates from the non-government sector and holding positions in the low profile departments in the Secretariat. For the moment Malaysia is an "under-represented" country in terms of staffing at the Commonwealth Secretariat. Malaysia's leaders have claimed that they wanted to play a high profile role in international affairs and, look at in this context, having a team of qualified and experienced 
Malaysians in this field would only provide them with up 'back-up' consultations or counsel at international forums and events but would also enable them to vie for senior positions in numerous international organizations, of which Malaysians are said to be far under represented.

Indeed, in 2007 Malaysia almost had a good chance of having its public figure holding the highest position in the Commonwealth Secretariat, to succeed out-going Secretary General, Chief Emeka Anyouku of Nigeria. The government had nominated Datuk Dr. Rais Yatim ${ }^{30}$, a cabinet minister, as one of four equally credible candidates vying for this position. According to the feedback conducted by Malaysia's Foreign Ministry, it gave the Malaysian candidate a good lead in that it was Asia's turn to hold that position. Unfortunately, about two months into the nomination Rais Yatim bowed out citing domestic commitments.

\section{Conclusion}

This article has shown that Malaysia's early foreign policy and the initial decision to accede and then to continue with Commonwealth membership was to a considerable extent a function of cordial relations between Malaysia and Britain, and shaped by the four successive Prime Ministers. These men, perhaps with some degree of exception for Hussein Onn, Abdullah Ahmad Badawi and the current Prime Minister, have brought distinctive styles to their office, and to Malaysia's foreign policy. Both Malaysia's foreign policy and the character of the Commonwealth changed quite considerably between 1957 and 2013, not least because of a changing regional and international context principally by the policies of successive Prime Ministers.

The achievement and benefits which Malaysia has derived from its 57 years' membership of the Commonwealth are still difficult to determine. The most visible instances in which the Commonwealth appeared to dominate Malaysia's foreign policy were during the Tunku's premiership, especially in the early post-independence years. During Indonesia's "Konfrontasi" against Malaysia, Commonwealth support was of value in a variety of ways.

The keen support which the Commonwealth enjoyed in Malaysia at the time of and for several years after independence had, by the end of 1981, diminished. The reasons for this change of attitude and priority stemmed from several considerations. First, the changing events in the Southeast Asian region in particular, and of the Commonwealth character in general. These afforded Malaysia the excuse to look for other intergovernmental regional organizations which, it was thought, could serve as important instruments for Malaysian foreign policy interests. Therefore, its membership of the ASEAN, the OIC and other intergovernmental organizations provide some explanation in this regard. Viewed in this light, it is certainly true that the more memberships any one state, or rather Malaysia holds, the less must be its commitment to any one particular organization, thus the Commonwealth could no longer be an instrument of first importance in Malaysia's political and economic 
policies. Secondly, the Commonwealth has always been seen by Malaysian elites at least being capable of fulfilling limited functional requirements. This cannot now be a major factor in Malaysia's development in particular, or for the developing countries within the Commonwealth, in general. Thirdly, the Anglo-centric sentiments among the new generation of Malaysian leaders and the articulate sections of the bureaucrats have diminished over time. Fourthly, there is a general lack of knowledge about the Commonwealth among Malaysians and the government as well as the main stream media, for their part, are doing little to explain and promote it. Finally, the strain in bilateral relations with Britain especially in the early 1980s was one of the main reasons for Malaysia's evident disenchantment with the Commonwealth.

Despite all this, Malaysia's connection with the Commonwealth has been retained. Malaysia's publicly displayed attitude towards this organization changed markedly when it played host to Kuala Lumpur CHOGM in October 1989 and the Commonwealth Games in 1998. The impact for hosting the Games, as can readily be seen, has not only helped strengthen Commonwealth links but also brought some tangible benefits to the development of sports in Malaysia. Though there is little evidence, however, to support that the hosting of these two major events indicated any strong or permanent change in Malaysia's foreign policy priorities in favour of the organization, certainly it reconfirmed Malaysia's continuing membership of as well as support for its existence. The Commonwealth is still of some importance and relevance to Malaysia, especially looking at Malaysia's active participation in the activities organized by Commonwealth Secretariat. Further, Malaysia's continuing membership can further help improve its image, especially when Malaysia wants to play an active and influential role in international affairs. Perhaps, given its potential, Malaysian leaders may in future find it more difficult to ignore and unnecessarily criticize this free association of equal members across the world. Again, if a member state is unhappy with an organization on the grounds of perceived ineffectiveness, the best solution is to be found from working within the organization rather than carping about in public.

\section{End Notes}

1 For detailed account of a transition from the British Empire into the Commonwealth, see Alfered, Z. (1934). The Third British Empire. London: Oxford University Press; McIntyre, W. D. (1974). Colonies into Commonwealth. London: Brandon Press; Cross, C. (1968). The Fall of the British Empire, 1918-1968. London: Hodder and Stoughton.

2 K. C. Wheare. (1952). The Constitutional Structure of the Commonwealth. London: Oxford Clarendon Press. p. 52.

3 Cross, J. A. (1984). Appraising the Commonwealth, Political Studies, vol. xxxii, p. 107.

4 Arnold, S., \& Clyde, S. (1981). Stitches in Time: The Commonwealth in World Politics. London: Andre Deutsch Limited. p. xix. 
5 Quoted in William, D. (1983). Is the Commonwealth an International Organisation. Commonwealth Law Buletin, 9(2). pp.635-55; J. D. B. Miller. (1958). The Commonwealth in the World. London: Duckworth. pp. 270-1.

6 J. D. B., Miller (1965). The Commonwealth in the World. London: Duckworth. pp. 270-1.

7 Ibid., p. 56.

8 Margaret, B. (1971). The “Open” Commonwealth. Durham: Duke University Press. p. 33.

9 Margaret, D. (1979). The Commonwealth Secretary-General: Limits of Leadership. International Affairs, 55(1).

${ }^{10}$ Cyriac, M. (1976). Nehru and the Commonwealth. New Delhi: Radiant Publishers. pp. 47-9.

${ }^{11}$ Interview with Tan Sri Ghazali Shafie, No. 3, 50 Queen's Gate, London on 10 May 1990.

${ }^{12}$ CO 1022/1025, February 1952, Public Record Office, London.

${ }^{13}$ For a fully documented account of the claim, see Ariff, M.O. (1970). The Philippines Claim to Sabah: Its Historical and Legal Implications. Kuala Lumpur: Oxford University Press.

${ }^{14}$ The Times. (1956, December 22).

15 Tunku Abdul Rahman. (1962, March 24). Speech at the Inauguration of the Malayan Branch of the Royal Commonwealth Society, Kuala Lumpur.

${ }^{16}$ Nicholas, M. (1958).Commonwealth Perspectives. Durham: Duke University Press. p. 123.

${ }^{17}$ Dewan Rakyat. (1971, July 26). col. 3713.

${ }^{18}$ New Straits Times. (1970, July 7).

${ }^{19}$ Full text of speech reproduced in Foreign Affairs Malaysia (June 1997). 10(2), pp.7-8.

${ }^{20}$ Quoted in Tunku Abdul Rahman. (1984). Contemporary Issues in Malaysian Politics. Petaling Jaya: Pelanduk Publications. p. 373.

${ }^{21}$ For a discussion on these issues, see Nazariah Osman, 'Malaysia and the Commonwealth: The Mahathir Era (1981-2003)', (unpublished PhD Thesis). Keele University, UK 2013, pp. 130-183.

${ }^{22}$ Mahathir Mohamed. (1971). Trends in Foreign Policy and Regionalism. In Patrick Low (Ed.). Proceedings and Background Papers on Trends in Malaysia. Singapore: Institute of Southeast Asian Studies. p. 33.

${ }^{23}$ Nazariah, 2013, p. 80. 
${ }^{24}$ Ibid., p. 82: For various views of FPDA see Ian.,Storey, R. Emeners, \& D. Singh. (eds.). (2011). Five Power Defence Arrangement at Forty. Singapore: Institute of Southeast Asian Studies.

${ }^{25}$ Quoted in the Malaysian Digest. (1982, July 31). 13(14). p. 2; see also The Star. (1982, July 16).

${ }^{26}$ Foreign Affairs Malaysia. (1990, June). 23(2), p. 10.

${ }^{27}$ See Muhammad, Muda. (2008). Malaysia at 50: Malaysia's Foreign Policy and the Commonwealth. In The Round Table, 97 (394), pp. 128-9.

${ }^{28}$ For an account of the impact and benefits of the Games to Malaysia, see Muhammad, Muda. (1998). The Significance of the Commonwealth Games in Malaysia's Foreign Policy. In The Round Table, no. 436.

${ }^{29}$ Margaret, D. (1975). International Organisation in Foreign Policy Perspectives. In Year Book of World Affairs. London: Stevens \& Sons. p. 191.

${ }^{30}$ For Rais's nomination, see New Straits Times. (2007, June 8 \& 9); On withdrawal see New Straits Times. (2007, July 26).

\section{References}

Ball, M. (1971). The "Open" Commonwealth. Durham: Duke University Press.

CO 1022/1025, February 1952, Public Record Office, London.

Cross, C. (1968). The Fall of the British Empire, 1918-1968. London: Hodder and Stoughton.

Dale, W. (1983). Is the Commonwealth an International Organisation. Commonwealth Law Buletin, 9(2).

Dewan Rakyat. (1971, July 26). col. 3713.

Doxey, M. (1975). International Organisation in Foreign Policy Perspectives. In Year Book of World Affairs. London: Stevens \& Sons.

Doxey, M. (1979). The Commonwealth Secretary-General: Limits of Leadership. International Affairs, 55(1).

Foreign Affairs Malaysia. (1990, June). 23(2).

Foreign Affairs Malaysia (1997, June). 10(2). 
Interview with Tan Sri Ghazali Shafie, No. 3, 50 Queen's Gate, London on 10 May 1990.

J.A., Cross. (1984). Appraising the Commonwealth. Political Studies, vol. xxxii.

Lloyd, L. (2007). Diplomacy with a Difference: the Commonwealth Office of High Commissioner, 1880-2006. Leiden: Martinus Nijhoff Publishers.

Low, P. (Ed.) (1971). Proceedings and Background Papers on Trends in Malaysia. Singapore: Institute of Southeast Asian Studies.

Malaysian Digest. (1982, July 31). 13(14).

Mansergh, N. (1958). Commonwealth Perspectives. Durham: Duke University Press.

Maprayil, C. (1976). Nehru and the Commonwealth. New Delhi: Radiant Publishers.

McIntyre, W. D. (1974). Colonies into Commonwealth. London: Brandon Press.

Miller, J. D. B. (1965). The Commonwealth in the World. London: Duckworth.

M. O., Ariff. (1970). ThePhilippines Claim to Sabah: Its Historical and Legal Implications. Kuala Lumpur: Oxford University Press.

Muda, Muhammad. (1998). The Significance of the Commonwealth Games in Malaysia's Foreign Policy. In The Round Table, no. 436.

Muda, Muhammad. (2008). Malaysia at 50: Malaysia's Foreign Policy and the Commonwealth. In The Round Table, 97(394).

New Straits Times. (1970, July 7).

New Straits Times. (2007, June 8 \& 9).

New Straits Times. (2007, July 26).

Osman, Nazariah. (2013). Malaysia and the Commonwealth: the Mahathir Era (1981-2003). (Unpublished PhD Thesis). United Kingdom: Keele University.

Storey, I., Emeners, R., \& Singh, D. (Eds.). (2011). Five Power Defence Arrangement at Forty. Singapore: Institute of Southeast Asian Studies.

Smith, A., \& Clyde, S. (1981). Stitches in Time: The Commonwealth in World Politics. London: Andre Deutsch Limited. 
The Star. (1982, July 16).

The Times. (1956, December 22).

Tunku Abdul Rahman. (1962, March 24) .Speech at the Inauguration of the Malayan Branch of the Royal Commonwealth Society, Kuala Lumpur.

Tunku Abdul Rahman. (1984). Contemporary Issues in Malaysian Politics. Petaling Jaya: Pelanduk Publications.

Wheare, K.C. (1952). The Constitutional Structure of the Commonwealth. London: Oxford Clarendon Press.

Zimmern, A. (1934). The Third British Empire. London: Oxford University Press. 
